\title{
Raising the age of criminal responsibility in the Republic of Ireland: a legacy of vested interests and political expediency

\author{
DERMOT WALSH*
}

University of Kent

\begin{abstract}
$\underline{\text { Abstract }}$
Throughout much of its history, juvenile justice in the Republic of Ireland has been oriented towards a justice as distinct from a welfare model. In the twenty-first century this was heavily amended pursuant to a justice agenda that emphasised criminalisation and punishment for offenders as young as 10 years of age. The treatment of the age of criminal responsibility has been an integral part of this trajectory. Raising the age of criminal responsibility from the common law low of 7 years in the Republic of Ireland has proved a surprisingly difficult endeavour. This article examines why the age of criminal responsibility in the Republic of Ireland was maintained at the common law age of 7 years, why there should have been such dithering over the reform when it eventually did come, and why the current law still criminalises children of a very young age. It argues that answers to these questions can be found in a volatile combination of religious values and interests, economic and social constraints, public intolerance of childhood offending, a lack of principled political leadership at the heart of the state, and the relative neglect of expert knowledge from the behavioural and neuro-sciences.
\end{abstract}

\section{Introduction}

$\mathrm{T}$ Throughout much of its history, juvenile justice in the Republic of Ireland has been oriented towards a justice as distinct from a welfare model. ${ }^{1}$ It was not until 2001 that the Children Act 1908 was finally replaced by a new statutory framework. It offered the promise of a more holistic model in which the welfare needs of young offenders could be managed without unduly depriving them of due process protections, or exposing them inappropriately to the stigmatisation and effects of criminalisation and punishment. ${ }^{2}$ Only five years later, before several of the key measures were even put into effect, it was heavily amended pursuant to a justice agenda that emphasised criminalisation and punishment for

* Professor of Law MRIA, Kent Law School.

1 For discussion of these models, see, for example, Anthony Doob and Michael Tonry, 'Varieties of Youth Justice' (2004) 31 Crime and Justice 1; Roger Smith, 'Welfare Versus Justice - Again!' (2005) 5(1) Youth Justice 3; Chris Cunneen and Rob White, Juvenile Justice: An Australian Perspective (OUP 1995) 190.

2 See, for example, Ursula Kilkelly, Youth Justice in Ireland: Tough Lives, Rough Justice (Irish Academic Press 2006) ch 2; Therese Lyne, 'Finding a Place for Juveniles in the Irish Criminal Justice System: Easy Question, Impossible Answer!' (2005) 4 Cork Online Law Review 11; Diarmuid Griffin, 'The Juvenile Conundrum: Ireland's Response to Youth Offending' (2003) Cork Online Law Review 12; Dermot P J Walsh, 'Balancing Due Process Values with Welfare Objectives in Juvenile Justice Procedure: Some Strengths and Weaknesses in the Irish Approach' (2008) 3(2) Youth Studies Ireland 3. 
offenders as young as 10 years of age. The treatment of the age of criminal responsibility has been an integral part of this trajectory. Indeed, the common law exposure of children as young as 7 years of age to the risk of punishment under the criminal law survived in independent Ireland for no less than 85 years.

Drawing heavily on the parliamentary record, this article examines why the age of criminal responsibility should have remained untouched for so long, why there should have been such dithering over the reform when it eventually did come, and why the current law still criminalises children of a very young age. It argues that answers to these questions can be found in a volatile combination of religious values and interests, economic and social constraints, public intolerance of childhood offending, a lack of principled political leadership at the heart of the state, and the relative neglect of expert knowledge from the behavioural and neuro-sciences. Before that, however, it is necessary to outline the relevant common law and statutory contexts.

\section{Common law background}

The common law system is generally believed to have supplanted the ancient Irish Brehon law system in Ireland by the seventeenth century. ${ }^{3}$ By that time, 7 years of age was taking root as the threshold for criminal responsibility at common law. ${ }^{4}$ A child older than 6 years and less than 14 years was deemed to lack the capacity to commit crime, but that presumption could be rebutted by proof that the child knew what he or she was doing was wrong. ${ }^{5}$ Holdsworth associated the emergence of a common law defence of infancy with the early development of the mens rea concept, in the sense of intent incorporating an element of moral wrong-doing. ${ }^{6}$ Equally, at that time, it began to be accepted that a child under 7 did not have the capacity to form the mens rea necessary to be guilty of a felony. Blackstone linked this more directly to the age when the child acquires a natural capacity to understand the difference between right and wrong. As Blackstone himself put it, the age 'when first the understanding might open'. ${ }^{7}$ Accordingly, he considered that for children under 7 years of age 'a felonious discretion is almost an impossibility in nature'. It would be tempting, therefore, to link the 7-year threshold for criminal liability with the Christian or Catholic doctrine that teaches that a child reaches the age of reason at 7 years and as such is deemed to have a sufficient understanding to commit sin and to be subject to ecclesiastical law. It is difficult, however, to find any explicit linkage between the two. Indeed, the Code of Canon Law does not refer to the age of reason at all. Instead, it refers to the use of reason. It was not until 1910 that Pope St Pius X issued the decree Quam Singulari which said that children reached the age of reason around the age of 7 , with discretion left to the family and priest. While 7 years of age was also recognised as having significance in terms of natural understanding and legal capacity in some other religions, there does not seem to have been any scientific, philosophical or cultural basis for the choice. Nevertheless, it seems that the common law also eventually settled on 7 years of age as the threshold at which a child acquired sufficient reason to ground criminal capacity.

3 Fergus Kelly, A Guide to Early Irish Law vol III (Institute of Advance Studies, Early Irish Law Series 1988) 26061; and, more generally, J Sinder, 'Irish Legal History: An Overview and Guide to the Sources' (2001) 93:2 Law Library Journal 231.

4 See, generally, William Blackstone, Commentaries on the Laws of England book 4 9th edn (Strahan and Cadell 1783) ch 2, 22-23; William S Holdsworth, A History of English Law vol 8 (Methuen \& Co/Sweet and Maxwell 1966) 438-39.

5 Glanville Williams, 'The Criminal Responsibility of Children' [1954] Crim LR 493.

6 Holdsworth (n 4) vol 3, 372-75.

7 Blackstone (n 4) 23. 
The common law on the age of criminal responsibility was retained without question in Ireland post-independence. ${ }^{8}$ Indeed, much of the law and legal process in the old state generally was incorporated largely unchanged in the new state. ${ }^{9}$ This was especially so in the area of juvenile justice. ${ }^{10}$ Surprisingly, perhaps, the low 7 -year threshold for criminal capacity was never challenged on constitutional grounds. At the very least, it might be considered that the expansive interpretation that has been given to the Article 38.1 concept of a trial in due course of law would provide a basis for challenging the notion that a child of 7 years of age could be criminally liable and punished for his or her actions. It may be, of course, that suitable opportunities for challenge rarely if ever arose due to a combination of the rebuttable presumption of incapacity for those over 6 years of age and less than 14 years of age and the reluctance of the state to prosecute children as young as 7 or 8 years of age.

\section{Statutory intervention}

The Children Act 2001, as originally enacted, stipulated that there was a conclusive presumption that no child under 12 years of age was capable of committing a criminal offence. ${ }^{11}$ This was complemented by a rebuttable presumption that a child who is not less than 12 years of age but under 14 years of age was incapable of committing a criminal offence because the child did not have the capacity to know that the act or omission concerned was wrong. ${ }^{12}$ These provisions retained the general common law approach to incapacity, but raised the age threshold for it by a very substantial five years. This meant that a child below the age of 12 years would be immune from criminalisation and the criminal process for his or her 'offending', although there was provision for the public Health Boards to intervene compulsorily in certain circumstances in the interests of his or her welfare. The rebuttable presumption in favour of a child's incapacity was retained for children of 12 and 13 years of age, but could be rebutted by proof that the child knew his or her act or omission was wrong, as distinct from the higher common law requirement of seriously wrong.

Without ever having been brought into effect, these reforms were replaced in 2006 by the current provisions which take a distinctly different approach to the age of criminal responsibility. In contrast to their predecessor and the common law, they do not set an age threshold below which a child is deemed wholly incapable of committing a criminal offence. Instead, they stipulate that, subject to specified exceptions, a child less than 12 years of age shall not be charged with a criminal offence. ${ }^{13}$ The exceptions are: murder, manslaughter, rape, rape under s 4 of the Criminal Law (Rape) (Amendment) Act 1990, or aggravated sexual assault. The protection against being charged with any of these offences only applies to a child less than 10 years of age. ${ }^{14}$ The net effect is that a child of 10 years of age can be charged, prosecuted, convicted and punished for any of these

8 See Green v Cavan County Council (1959) Ir Jur Rep 75; Monagle v Donegal County Council (1961) Ir Jur Rep 37; KM $v$ DPP [1994] 1 IR 514; Summary Jurisdiction Over Children (Ireland) Act 1884, s 4. For discussion, see Nial Osborough, 'Rebutting the Presumption of Doli Incapax' (1975) X Irish Jurist 48; Conor Hanly, 'The Defence of Infancy' (1996) Irish Criminal Law Journal 72; Conor Hanly, 'Child Offenders: The Changing Response of Irish Law' (1997) 19 Dublin University Law Journal 113.

9 See Raymond Byrne and Paul McCutcheon, Byrne and McCutcheon on the Irish Legal System 5th edn (Bloomsbury Professional 2009) 2.64-65.

10 See Dermot P J Walsh, Juvenile Justice (Thomson Round Hall 2005) 1-01-08.

11 Children Act 2001, s 52(1), as originally enacted.

12 Ibid s 52(2).

13 Children Act 2001, s 52(1), as substituted by Criminal Justice Act 2006, s 129.

14 Ibid s 52(2). 
serious offences, while a child less than 12 years of age cannot be charged with any other offence. Critically, the old rebuttable presumption that had applied between the ages of 7 and 14 years is abolished. ${ }^{15}$ In its place is a general provision to the effect that in any case where a child below the age of 14 years is charged with an offence, no further proceedings in the matter, apart from remand in custody or on bail, can be taken except by or with the consent of the Director of Public Prosecutions. ${ }^{16}$

The wording of the current statutory provisions is striking. For the first time in the history of Irish law, it dispenses with a clear statement of principle that a child below a specified age is deemed incapable of committing a criminal offence. This ancient precept is replaced by a functional stipulation to the effect that a child below a certain age cannot be charged with an offence. In other words, it adopts the formulation familiar to Scottish law and many European civilian procedures that operate in a different context. ${ }^{17}$ What is not so clear is whether the conclusive common law presumption of incapacity for children below the age of 7 years is also abolished. The wording in the 2001 Act, as originally enacted, left no doubt that the intention was simply to raise the common law age threshold to 12 years; the automatic implication being that a child below the age of 12 years lacked the capacity to commit a criminal offence. The wording of its 2006 replacement, however, is more ambiguous. Not only does it introduce the concept of different age thresholds for different offences, but it also drops the language of criminal incapacity in favour of the language of protection against being charged. The common law incapacity attaching to children below the age of 7 years is not expressly abolished. It is just ignored. It can be argued, of course, that it is implicitly replaced by the introduction of the statutory provisions. It can equally be argued, however, that there is no inherent incongruity in saying that a child below the age of 7 years lacks capacity to commit a criminal offence while, at the same time, stipulating that a child below the age of 12 years (or 10 years, as the case may be) cannot be charged with a criminal offence. The latter does not necessarily entail the demise of the former.

Even if the common law capacity threshold has not been abolished, it seems clear that Irish criminal law has at least retreated from express recognition of a concept of childhood innocence, in the sense of a child of a very young age lacking the inherent capacity to commit crime. Instead, such children are viewed as the equivalent of adults in terms of criminal capacity and their distinctive status and vulnerability are catered for merely by a procedural bar on their being charged with a criminal offence so long as they are below the age of 10 or 12 years depending on the 'offence'. The net effect is that, where a child of, for example, 7 or 8 years of age (or even younger if the common law threshold has been implicitly abolished) acts in a manner that could constitute a criminal offence, the unseemly spectacle of the child being prosecuted and punished through the criminal law is avoided only on account of the procedural bar on being charged. The child's behaviour, however, can still be classified as 'criminal' for other official record purposes, with all the consequences that that can have for the status of the child. Indeed, the change effected in 2006 expressly provides for children of 10 and 11 years of age to be admitted to the Garda Juvenile Diversion Programme for young offenders. Similarly, children in these age categories can be referred to the Garda Diversion Programme for 'offending' and antisocial behaviour. Moreover, it is now expressly provided that evidence of a child's involvement in the Diversion Programme is admissible for sentencing

15 Ibid s 52(3).

16 Children Act 2001, s 52(4), as substituted by Criminal Justice Act 2006, s 129.

17 See Frieder Dünkel, Joanna Grzywa, Philip Horsfield and Ineke Pruin, Juvenile Justice Systems in Europe: Current Situation and Reform Development vols 1-4 (Forum Verlag Godesberg 2010). 
purposes in the event of subsequent criminal proceedings against the child. ${ }^{18}$ It is difficult to avoid the conclusion that, under the current regime, the age-old acceptance that children below a certain age are simply too innocent to be associated with the tag 'criminal', has given way to a popular demand that they should at least be stigmatised for their 'criminality', even if it is not appropriate to prosecute and punish them for it through the criminal process. This aspect is pursued further below.

A further devious twist in the wording of the current law is that it does not actually provide a child, no matter how young, with an explicit and absolute protection against being charged, prosecuted and punished in respect of a criminal offence. The statutory provision in question states that a child under the age of 12 years, or 10 years (as the case may be), shall not be charged with a criminal offence. Clearly, it is framed in terms of the age of the child when charged, as distinct from the age of the child when he or she committed the 'offence'. In other words, it does no more than protect a child against being charged with an offence while the child is below the age of 12 (or 10) years. It does not positively protect a child who has reached his or her 12th (or 10th) birthday from being charged, convicted and punished for a criminal offence committed when that child was less than 12 (or 10) years of age.

The current provisions clearly reflect a less tolerant view of offending by young children than their predecessors which had never actually been brought into force. The factors that produced this result were also active in sustaining the common law threshold on the age of criminal responsibility for 85 years.

\section{Religious, social and economic factors sustaining the common law threshold}

The fact that the common law threshold survived in Ireland until 2006 is surprising given that it had been raised to 10 in England and Wales in 1963 and in Northern Ireland in 1968. The regular practice of criminal law reforms in these neighbouring jurisdictions being adopted some years later in the Republic of Ireland clearly did not extend to the age of criminal responsibility. This suggests that the low common law threshold was deeply rooted in the indigenous social and cultural values. Significantly, when the Children Act 1934 was introduced to extend supervisory safeguards for orphaned children in private care homes from 7-year-olds to 9-year-olds, there was no mention in the parliamentary debates of raising the age of criminal responsibility in line with the recent increase to 8 in England and Wales in 1933. This is despite the fact that the 1934 Act had clearly been lifted from a part of the UK Act that also raised the age of criminal responsibility. The silence is even more striking given that, when introducing the measure in Parliament, the parliamentary secretary to the Minister for Health actually said that the age for local supervisory control was being raised from 7 years to 9 because 7 'was a rather tender age to release the child from the protective provisions of the Act'. ${ }^{19}$

With respect to Ireland of the 1920 s through to at least the 1970 s, it is easy to draw a correlation between this unquestioning acceptance of the 7-year threshold with Catholic teaching and religious practice. Not only was the religious affiliation and identity of the populace overwhelmingly Catholic, ${ }^{20}$ but the management of mainstream schooling was

18 Children Act 2001, s 48(2), as substituted by Criminal Justice Act 2006, s 126. For criticisms of these aspects, see Ursula Kilkelly, Children's Rights in Ireland: Law, Policy and Practice (Tottel 2008) 13.017-19.

19 Seanad Debates 11 April 1934, vol 8, no 14, 970.

20 On the influential role of the Catholic Church on social and political life in the state up to and including the 1970s, see John H Whyte, Church and State in Modern Ireland 1923-1979 (Gill \& Macmillan 1980); Tom Inglis, Moral Monopoly: The Rise and Fall of the Catholic Church in Modern Ireland 2nd edn (UCD Press 1998); Brian Fallon, The Age of Innocence: Irish Culture 1930-1960 (Gill \& Macmillan 1960) ch 14. 
also dominated by the Catholic Church and Catholic religious orders. ${ }^{21}$ These factors combined potently in admission to the Catholic sacrament of the Eucharist. Known generally as the 'First Communion', it had a central place in the lives of most young children throughout the country, as well as for their families and primary schools. Critically, the 'First Communion' was synonymous with acquiring the capacity to reason, in the sense of being able to distinguish between right and wrong (often taught in the schools as reaching the age of reason). So universal and familiar was this teaching and practice at all levels of Irish society and parts of the country that it is easy to see how the age of 7 would have been accepted unquestioningly as the natural threshold for exposing children to punishment not just for sin, but also for crime.

It can also be argued that there were certain religious-based vested interests in maintaining a low age of criminal responsibility in Ireland, at least throughout the early decades of the state's existence. Industrial (and reformatory) schools which provided accommodation and education, and generally stood in loco parentis for certain categories of vulnerable young children, were almost wholly owned and managed by religious orders. ${ }^{22}$ The children committed to them were orphaned or destitute or were convicted and sentenced in criminal matters. Critically, the school owners were paid a subvention for each child detained in their school. Accordingly, the children were a valuable and necessary source of income for the religious orders in respect of their own maintenance and that of the properties concerned. A rare estimates debate on the annual subvention revealed a concern that the financial viability of the schools, and by extension, the religious orders who owned and managed them, was threatened by the courts not sentencing enough young children to be detained in them. This was reflected starkly in the following contribution from one member:

I know that the number of boys that should be in Glencree [Reformatory], and in other schools, should not be 76, but should be 700. It would be better to have them there for the reason that they would be taken away from their present surroundings, where they have little but bad example before them. Their parents, perhaps, may be people who are sent to jail occasionally, or it may be that their parents are drunkards, as unfortunately too often is the case. It is unfortunate that magistrates should take the view that so many of them do take in dealing with boys of this class. If you had 700 pupils in those schools you would not be faced with the financial position that you are in to-day. That financial position has largely been brought about by the unfortunate attitude of mind of both parents and magistrates to these schools, which are really very estimable schools. ${ }^{23}$

More than 10 years later, a member of the Dail, speaking in the debates on the Children Bill 1940, observed more bluntly:

I have heard it said by responsible people at meetings of public bodies in this city [Dublin] that children were very often committed to these institutions not so much because it was felt that it was in their own interest to commit them, but because it was very good for the institutions in question. ${ }^{24}$

21 See, for example, Whyte (n 20) 16-21.

22 For accounts of the establishment, management and operation of these schools, see Jane Barnes, Irish Industrial Schools 1868-1908 (Irish Academic Press 1989); Report of the Commission to Inquire into Child Abuse (the Ryan Report) (Stationery Office 2009); Dermot P J Walsh, Juvenile Justice (Thomson Round Hall 2005) ch 9. See Walsh for further sources on life for some children in them.

23 Dail Debates 18 June 1925, vol 12, no 11, 1278.

24 Dail Debates 11 November 1940, vol 81, no 7, 1125. 
Obviously, the lower the age of criminal responsibility, the greater the flow of child 'offenders', and associated income, to the industrial schools. Disturbingly, criminal law and practice seemed to bend too readily in favour of fuelling a steady supply of both from the state to the religious orders. The law afforded District Court judges very broad discretion in ordering young offenders to be detained in these schools for very long periods. $^{25}$ Despite some of the concerns expressed in the 1925 estimates debate, too many judges were too willing to commit young children convicted of minor offences to detention in the schools for very long periods, purportedly in the interests of their educational, moral and social development. In the course of the debate, for example, one member raised the case of a 10 -year-old child from a stable family who was ordered to be detained until he was 16 after being convicted of breaking into a paper shop with others to get fuel for a bonfire to celebrate a local election victory. ${ }^{26}$ Another case highlighted in the Dail during these years concerned the sentencing of four children for a minor act of vandalism in which electrical insulators worth about $£ 2$ each were broken. For these offences, two 14-year-old children were ordered to be detained in a reformatory for 5 years, while an 11-year-old and a 9-year-old were each ordered to be detained in an industrial school for 3 years. An appeal for intervention from the minister met with a cold and dismissive response to the effect that such action was necessary to deter boys from engaging in breaking insulators in the area. ${ }^{27}$

It would be unfair, however, to paint a picture of church and state conspiring to use the criminal law and justice system as a source of financial maintenance for the religious orders. The sad reality is that in the early decades of the state, some families were so desperate that they coveted the consignment of one or more of their young children to an industrial school. They considered that the food, accommodation and education on offer there would far outweigh the life-threatening destitution that would be their lot within the family. Accordingly, it was not uncommon for parents to engineer the conviction of their own children for petty offences, such as begging, in the hope that they would be convicted and sentenced to detention in an industrial school. ${ }^{28}$

\section{Emergence of voices for reform}

It was not until the 1960s and 1970s that disparate voices in favour of raising the age of criminal responsibility began to surface in Ireland. For the most part, these were confined primarily to academics, practitioners and individuals or bodies commissioned to carry out research on the juvenile justice system. The most substantial of these was surely the Kennedy Committee which was established in 1967 by the Minister for Education to examine the industrial and reformatory school system. It reported in 1970 with wideranging reforms based on extensive research and rigorous reasoning, ${ }^{29}$ as befits its able and experienced membership. ${ }^{30}$ Among its many weighty recommendations, which have stood the test of time, is that the age of criminal responsibility should be increased to 12 years and that a civil, welfare-based procedure should be introduced to address the needs

25 Walsh (n 22) 7-26-77.

26 Dail Debates 18 June 1925, vol 12, no 11, 1279.

27 See Dail Debates 28 March 1928, vol 22, no 7, 706.

28 See Dail and Seanad debates on the Children (Amendment) Bill 1928; Dail Debates 28 February 1929, vol 28, no 5, and Seanad Debates 20 June 1928, vol 10, no 18.

29 Report of the Committee on Reformatory and Industrial Schools Systems (Stationery Office 1970).

30 See Anthony Keating, 'A Contested Legacy: The Kennedy Committee Revisited' (2013) 22(3) Irish Studies Review 304, for insights into the composition and approach of the Committee and on why its recommendations were not implemented. 
of children who 'offend' below that age. ${ }^{31}$ Significantly, this recommendation was not based on a simple linkage with thresholds in neighbouring and many other European jurisdictions where the minimum age had been significantly higher than that in Ireland for many years. Instead, the Committee conducted a thorough and sophisticated analysis into the causes of juvenile delinquency. It concluded that the most important causal factors were the personality and emotional development of the individual juvenile. Sadly, as will be seen later, this is the vital aspect that seems to have been lost when the state finally managed to reform the law on the age of criminal responsibility.

The case for an increase in the age of criminal responsibility was also made in various other reports, studies and papers over the next few decades. ${ }^{32}$ The elected members of Parliament, however, were initially more reticent in highlighting the issue, preferring to follow rather than lead. The first significant Dail debate was triggered accidentally in 1984 by a misunderstanding on the part of some members with respect to the likely application to young children of what was to become the Criminal Justice Act 1984. This Act introduced, for the first time in Ireland, a general police power to detain arrested suspects for the investigation for crime - along the lines of the Police and Criminal Evidence Act 1984 in Britain. Unnerved by the prospects of children of 7 and 8 years of age being detained for investigation in Garda custody, some members forced a debate on an amendment seeking to raise the age of criminal responsibility to at least 12 years of age. While the amendment was lost, the debate did seem to reflect a broad consensus among the members that the age of criminal responsibility was too low at 7 years of age. Perhaps more significant, in light of future developments, were the implicit indications of a lack of consensus on what the age should be and on how it should be achieved. As will be seen below, many members voiced concerns about what they viewed as the criminal behaviour of children of 9,10 and 11 years of age and strongly favoured the application of harsh punitive measures to deal with it. In 1986, the Dail Select Committee on Crime, Lawlessness and Vandalism displayed a lack of conviction on raising the age of criminal responsibility when it opted not to make recommendations after having reviewed the law on it. ${ }^{33}$ Similarly, in 1988, on the first occasion that a concrete legislative proposal was put before the Dail, it generated protestations of consensus on the need to raise the age, but no political will to deliver on it. ${ }^{34}$

It was not until 1992 that a Dail Select Committee on Crime felt sufficiently confident to recommend raising the age of criminal responsibility. ${ }^{35} \mathrm{By}$ that time, however, there was a general expectation that the government was set to bring forward legislative proposals to raise the age. In the event, those proposals did not see the light of day until 1996 and, as indicated above, it was a full 10 years later in 2006 before the age was raised in effect. Clearly, underneath the apparent consensus among the experts and parliamentarians, there were strong undercurrents moving in the opposite direction.

31 The report was reviewed favourably by Nial Osborough in 'Reformatory and Industrial Schools' (1970) Irish Jurist 294.

32 See, for example, Report of the Commission of Enquiry into the Irish Penal System (Michael MacGreil 1980); Helen Burke, Claire Carney and Geoffrey Cooke (eds), Youth and Justice: Young Offenders in Ireland (Turoe Press 1981); John Farrelly, Crime, Custody and Community: Juvenile Justice and Crime with Particular Relevance to Sean McDermott Street (Voluntary and Statutory Bodies 1989); Eoin O'Sullivan, Juvenile Justice in the Republic of Ireland: Future Priorities' (1996) Irish Social Worker 14; National Youth Federation, Policy for Juvenile Justice: Justice for Young People (Irish Youth Work Press 1996); National Crime Forum, Report of the National Crime Forum 1998 (IPA 1998).

33 Thirteenth Report of the Select Committee on Crime, Lawlessness and Vandalism (Dublin PL 4506, 1986).

34 Special Committee Child Care Bill 1988 Debate (31 May 1990) 3.

35 First Report of the Select Committee on Crime (Dublin 1992). 


\section{Latent forces impeding reform}

Although the age of criminal responsibility was eventually raised in 2006, initial attempts within government to formulate legislative proposals to that end actually commenced 25 years earlier in 1981. The apparent consensus on the need for reform that emerged in the course of the 1980s concealed an underlying lack of agreement on the shape that that reform should take. Permeating the latter was a volatile combination of religious, social, economic and political forces that were not conducive to a simple raising of the incapacity to commit crime from 7 years to a significantly higher level. These forces were not always visible or consistent. It may also be no exaggeration to say that some powerful political sources maintained a hypocritical public image of support for raising the age, while privately working to frustrate it. Ultimately, the net effect of these negative forces was not just a delay for more than two decades, but also a significant dilution of the substance of the initial proposals.

Much of the initial delay in bringing forward concrete legislative proposals on raising the age of criminal responsibility can be attributed directly to a mixture of old-fashioned 'turf' wars and administrative disharmony behind the scenes within the relevant government departments. Traditionally, juvenile justice entailed overlap between the Departments of Justice and Education, while the Department of Health dealt with the care needs of children outside of the criminal justice system. Raising the age of criminal responsibility to 10 or 12 or higher would present difficult questions of how to deal with the significant numbers of such children who were engaged in serious and, in some cases, persistent offending. Some means of facilitating compulsory intervention for the care and welfare of these children would have to be provided. This, in turn, raised issues of whether and, if so, how Ireland should implement mechanisms such as the civil judicial hearings applicable to young offenders of 8 to 12 years of age in Scotland, ${ }^{36}$ or equivalent mechanisms familiar in many European continental jurisdictions. ${ }^{37}$ The three government departments failed to reach a coherent position on how these aspects should be addressed and managed. The net result was that legislative proposals on child care and juvenile justice were separated. The former were introduced in Parliament in the form of a Child Care and Protection Bill 1985, which was not actually enacted until 1991. It took another 5 years, and the establishment of a single coordinating Minister of State with responsibility for children's affairs in each of the three departments, before legislative proposals on juvenile justice first appeared in Parliament. ${ }^{38}$

The pervasive, albeit indirect, influence of the Catholic Church can be detected in the obstructionism faced by the Child Care and Protection Bill. Critically, the Bill included provision for the essential welfare-based measures needed to cope with young offenders who would be put beyond the reach of the criminal justice system by a significant raising of the age of criminal responsibility. This entailed conferring civil powers on the state to take children away from families in situations where the child was not at risk or orphaned or destitute. Just how controversial that would prove to be is indicated by the special status afforded the sanctity of the family by the Constitution. Reflecting the influence of the Catholic Church, 39 Article 41.1 of the Constitution stipulates that ' $[\mathrm{t}]$ he State recognises the Family as the natural primary and fundamental unit group of Society, and

36 See Claire MacDiarmid, 'Age of Criminal Responsibility: Raise it or Remove it?' (2001) 5 Juridical Review 243.

37 Frieder Dünkel et al (n 17).

38 See Dail Debates 12 February 1997, vol 474, no 7, 1308.

39 See Dermot Keogh and Andrew McCarthy, The Making of the Irish Constitution 1937 (Mercier Press 1997) especially chs 3 and 4 . 
as a moral institution possessing inalienable and imprescriptible rights, antecedent and superior to all positive law'. Faced with such powerful, absolute and trenchant language, it was always going to be difficult for the state to secure the powers and establish the civil process necessary to override parental authority to the extent of removing a child from the family in the interests of his or her own welfare and development. It is no surprise, therefore, that it took 6 years and several diversions before the 1985 child-care measures even made it to the statute book.

The potential economic costs of the welfare supports that would have to be provided to manage the increase in underage child offenders also proved a potent factor in shaping the content and progress of the legislative proposals. Ireland in the 1980s lacked the infrastructure and resources necessary to provide the appropriate facilities and services. As noted above, it had always relied heavily on the resources of the church and the voluntary private sector to provide the accommodation, social and educational needs of children sentenced to detention or committed to care. Raising the age of criminal responsibility was likely to force the state to invest heavily in providing the necessary supports. This was a prospect that many in the political establishment were loathe to entertain.

The other potent factor affecting the progress and content of the proposals to raise the age of criminal responsibility was public opinion. The nature and extent of offending by children as young as 10 years of age was an issue of acute public concern throughout the 1980s and 1990s and beyond. While it may not have reached the levels necessary to satisfy all of the criteria for a 'moral panic', there was a deep sense of public alarm and anger at the prevalence of joyriding, glue-sniffing, vandalism and antisocial behaviour, all of which were associated in the public mind with children out of control in parts of the urban centres. The media reporting of such activities produced an effect similar to that generated in the UK in the wake of the killing of toddler Jamie Bolger by two 10-yearold boys. ${ }^{40}$ Indeed, in Ireland there was also a spill-over effect of the media reporting of that killing. Not surprisingly, in this toxic environment, suggestions to increase the age of criminal responsibility were always likely to provoke fears among the communities affected that they would be left powerless and abandoned in the face of young criminals who would be above and beyond the reach of the law. ${ }^{41}$ These fears were reflected in the content and tone of the contributions from their elected representatives to the debates from the mid-1980s through the 1990s and beyond on each occasion that proposals were tabled to increase the age of criminal responsibility. While they generally accepted the argument that 7 was too low, they needed reassurance that any move to increase it would be marginal and/or would be accompanied by alternative control mechanisms. This position was captured neatly by the Minister of State at the Department of Health when, in responding to a proposal to raise the age of criminal responsibility to 12 years in the course of the debates in the Child Care Bill 1988, he said:

If we agree to provide in law that children under 14 years are not capable of committing crimes, there would be widespread public concern at the prospect of youngsters committing anti-social acts and not being subject to any form of punishment or sanction. 42

40 See, for example, Eleanor T Leane, 'The Principles of Juvenile Justice No Longer Apply when Children Commit Serious or Violent Crime' (2007) Cork Online Law Review 3; Lyne (n 2).

41 See Diarmuid Griffin, 'The Juvenile Conundrum: Ireland's Response to Juvenile Offending' (2003) Cork Online Law Review 12. The Kennedy Report adverted to this risk as far back as 1970; Task Force on Child Care Services, Final Report (Stationery Office 1980).

42 Special Committee (n 34) 3. 
And later:

I think that the man in the street would be appalled at the suggestion that such youngsters could not be prosecuted. ${ }^{43}$

The minister's comments indicate that it would not be acceptable for child offenders between the ages of 7 and 14 years to be managed solely through a civil, welfare-based process. There also had to be an element of just desserts and overt punishment. This reflected a strong current of Irish public opinion that was intolerant of childhood offending and wedded to the need to discipline children severely in order to steer them away from wrong-doing (and its close association with sin) at a young and impressionable age. The emphasis was very much on discipline through corporal punishment coupled with the application of a rigorous education and lifestyle regime aimed at selfimprovement and the production of obedient children in the image of the traditional Irish Catholic model of the child. Once again, the dominant influence of Catholic religious forces within the family and the state was both apparent and real. As noted above, the state relied heavily on the religious orders, through their industrial (and reformatory) schools, to shoulder the burden of rehabilitating very young offenders and steer them away from criminal and antisocial behaviour. Corporal punishment was a regular instrument for imposing discipline in those schools and in the mainstream schools, most of which were either owned by religious orders or managed by the church. ${ }^{44}$ It was not formally prohibited by law in the detention schools until 2007.

These values came to the surface in the parliamentary process in debates on juvenile crime and justice in the 1990s. In an adjournment debate on the lack of secure accommodation for young offenders, for example, a future Minister for Justice, who would later oversee the enactment of the Children Act 2001, said:

[The] time has come for us to provide adequate detention facilities for young offenders. They are now getting the same simple and lucid message as hardened criminals: if one commits a serious criminal offence, the punishment will not fit the crime. I believe that, not only in this case but in the case of virtually everybody who has the use of reason, there is a crying and desperate need for this State to tell those who commit serious crimes that the punishment will fit the crime and that if they commit a serious criminal offence, not only will they go to prison or a place of detention but they will stay there until they have served their debt to society or be made an example of to others who might be of like mind. ${ }^{45}$

Previously, in the debates on the Criminal Justice Bill 1983, several members attributed juvenile crime to the demise of corporal punishment in the schools, and called for the return of birching and the introduction of army-type detention camps because 'young people need discipline'. ${ }^{46}$

This public opinion context helps to explain why it took so long for concrete legislative proposals on raising the age of criminal responsibility to be brought forward by the government in Ireland. It also helps explain the slow and torturous journey of those proposals into law at a time when, at least superficially, it appeared that there was a general consensus on the need to raise the low age threshold. This journey was further

43 Ibid.

44 For insights into life in these schools for some children, see Mary Raftery and Eoin O'Sullivan, Suffer the Little Children: The Inside Story of Ireland's Industrial Schools (New Island 1999); Harry Ferguson, 'States of Fear, Child Abuse and Irish Society' (2000) 50(1) Doctrine and Life 20; Ryan Report (n 22).

45 Dail Debates 12 March 1996, vol 462, no 8.

46 Dail Debates 10 and 15 November 1983, vol 345, nos 10 and 11. 
complicated by the arguably duplicitous approach of the largest political party and its allies in Parliament.

\section{Political expediency}

The remarkable legislative journey that eventually culminated in a raising of the age of criminal responsibility began with the Children Bill 1996 introduced by a Fine Gael and Labour coalition government. Constrained by public opinion and the limited financial resources of the Health Boards to cope with the extra offenders outside of the criminal justice system, it adopted 10 years of age as the threshold for criminal responsibility. ${ }^{47}$ Critically, it did this simply by extending to 10 years of age the existing conclusive presumption that children below 7 years of age lacked the capacity to commit crime. ${ }^{48}$ Offenders below 10 years of age would be dealt with by the Health Boards wholly outside the criminal justice system on an exclusively welfare basis. The conclusive presumption was accompanied by a rebuttable presumption that a child from 10 years to 13 years of age inclusive was incapable of committing a criminal offence because he or she did not know the act or omission concerned was wrong.

Although the proposal was generally welcomed as a long overdue step in the right direction, underneath the superficial consensus lurked an embedded, but largely unspoken, resistance within the Fianna Fail and Progressive Democrat opposition parties. Fianna Fail failed to cooperate with the government in moving the Bill on to the Committee stage and so it had progressed no further when the government collapsed in June 1997. Under pressure from the UN Committee on the Rights of the Child, ${ }^{49}$ the Bill was reintroduced by the new Fianna Fail-Progressive Democrat coalition in February 1998 with an actual increase in the age of criminal responsibility to 12 years. Nevertheless, the government continued to drag its heels in the matter and debate on the Bill did not resume until February 2001. When introducing the Bill on second stage in the Seanad on 20 June 2001, the Minister of State at the Department of Health and Children explained that children under the age of 12 will no longer have the capacity to commit a criminal offence. This, she said, 'was based on the belief that as a society we should not criminalise children under 12 years of age; that the alternative policy for intervening with such children, that is, by the health boards, often in concert with other agencies, was credible; and that health board personnel would deal with these children in their usual professional manner'. Nevertheless, these sentiments were to prove false as the provisions were never brought into effect, purportedly because of their financial costs and public intolerance of serious crime being committed by 10 - and 11 -year-olds. ${ }^{50}$ As explained above, they were replaced in 2006 by another Fianna Fail-Progressive Democrat coalition with a version that resonated an overtly justice-oriented approach to the management of very young child offenders.

The manner in which the current provisions were introduced can only be described as extraordinary and bordering on the undemocratic. It seems that the superficial consensus

47 While Hanly generally welcomed the Bill as a whole, he viewed it as much less revolutionary in its time than the Children Act that it was intended to replace; see Hanly, 'Child Offenders' (n 8).

48 It also included provision to keep the age threshold under review with a view to raising it to 12 years when economic resources would allow.

49 The UN Committee considered Ireland's first report in January 1998. It was highly critical of the proposed 10-year-old threshold and emphasised a preference for a minimum of 12 years of age; UN Committee on the Rights of the Child, Concluding Observations: Ireland (CRC/C/15/Add 85) para 23. In 2005, the Minister of State for Children openly acknowledged that the 12-year threshold in the 2001 Act was adopted to appease the UN Committee; Seanad Debates 16 November 2005, vol 181, no 70, 1516.

50 See debate on juvenile offenders motion; Seanad Debates 16 November 2005, vol 181, no 70. 
that produced the 2001 Act was swept aside in an underhand manner by those latent reactionary forces that were never fully supportive of the 2001 consensus. ${ }^{51}$ The vehicle was a Criminal Justice Bill from 2004 that was still making its way through the legislative process in 2006. After that Bill had completed its second reading, the Minister for Justice stunned the Dail by announcing his intention to introduce a whole raft of substantive amendments at committee stage. These were so substantive and voluminous that they dwarfed the original Bill. Critically, they embraced major innovatory and draconian measures to tackle organised crime, violent offences, drug-trafficking and firearms offences, as well as major changes and additions to the Children Act 2001. As seen above, the changes included a significant rewriting of the provision in the 2001 Act on the age of criminal responsibility. In any normal democratic process, these changes to the children legislation would have been introduced and debated as a separate Bill. Lumping them in with the draconian provisions on gangland crime ensured that they would largely escape parliamentary scrutiny as attention would focus on the other measures, given that there was something of a media-driven 'moral panic' over gangland crime at the time. Not surprisingly, that is exactly what happened as, in the debate that followed the minister's introduction of the amendments, only one member highlighted the government's retreat from the juvenile justice principles in the 2001 Act.

The undemocratic effects of this strategy were compounded by the manner in which the ministerial team obscured, and even distorted, the substance of the changes in the age of criminal responsibility. The 'Jamie Bolger' case was called in aid of the reduction in the age of criminal responsibility from 12 years in the 2001 Act to 10 years in respect of certain of the most serious offences (see below). When challenged on the relevance of the case in Ireland, the minister resorted to grossly exaggerated scenarios which simply would not occur under the measures enshrined in the 2001 Act as originally enacted. He said:

There have been a few cases of sexual offences involving minors. A solid citizen could wake up one morning to realise that the young boy who had raped his or her daughter was going back to school that day and there would be a conference, or that a person who pushed his or her child under a train or into a canal was back at school, or that a person had bullied and tortured a person. If our law was such that these people would be given a mere slap on the wrist and told to get on with the rest of their lives, public opinion would be outraged. ${ }^{52}$

Moreover, no mention was made of the significant shift from replacing the conclusive presumption that a child under 12 years of age lacked the capacity to commit an offence with protection against being charged with an offence (see below). No explanation was given for the abolition of the rebuttable presumption. Most cynically, these changes were presented as being motivated by a desire to raise the age of criminal responsibility without delay.

\section{Conclusion}

Raising the age of criminal responsibility in the Republic of Ireland has proved a surprisingly difficult endeavour. The view of criminalisation and punishment as essential, even natural, tools for dealing with offending by young children was so deeply rooted in Irish society that it was the 1980 s before a consensus began to emerge on the need to raise the age from the common law low of 7 years. The laboured attempts to implement that consensus over the next 25 years are a testament to the strength and depth, and ultimate

51 For a critique of the disappointing implementation of other key aspects of the 2001 Act, see Ursula Kilkelly 'Diverging or Emerging from Law? The Practice of Youth Justice in Ireland' (2014) 14(3) Youth Justice 212. 
success, of forces wedded to the more traditional view of childhood and punishment. Contrary to the threshold promoted as a minimum by the UN Committee on the Rights of the Child, children from 10 years of age in Ireland are subject fully to the criminal law and punishment for the most serious crimes. While it may appear that children below 12 years of age are beyond the reach of the criminal law, the reality is that they too are not fully immune from its effects.

A disappointing feature of the policy debates on the subject in Ireland over the past 30 years is that they have not embraced, or even engaged with, the body of expert knowledge on the development of cognitive reasoning in children that has come to the fore over that period. Advances in the behavioural and neuro-sciences show that setting an arbitrary age for attaching criminal liability is likely to penalise many children unfairly. Reviewing the literature, McDiarmid explains that the cognitive development necessary to integrate rational control over functioning with the level of skills and functional ability acquired are individual to the child. ${ }^{53}$ Not only does this argue against the universal application of a fixed age, but it also suggests that even 12 years of age may be too low as a generalisation. ${ }^{54}$ Although the Kennedy Report back in 1980 raised these issues in its analysis of juvenile crime, they have not had any impact on the ensuing debate, which has been dominated variously by the need to bring the law into line with standards in the neighbouring jurisdictions, the benefits of diverting the child from the criminal process, placating the UN Committee on the Rights of the Child and, ultimately, a perceived need for strict discipline as a primary tool to combat childhood offending. It would appear, therefore, that the case for reform is still as pressing in the Republic of Ireland as it is in its neighbouring jurisdictions.

53 See Claire MacDiarmid, 'An Age of Complexity: Children and Criminal Responsibility in Law' (2013) 13(2) Youth Justice 145.

54 The Royal Society, Brain Waves Module 4: Neuroscience and the Law (Royal Society Policy Document 5/11 2011) 3.2. Delmage suggests that it points in favour of a minimum age of 14 years; see Enys Delmage, 'The Minimum Age of Criminal Responsibility: A Medico-Legal Perspective' (2013) 13(2) Youth Justice 102. 